\title{
The effects of taping and exercise on ankle joint movement in subjects with functional instability (FI) of the ankle joint during a jump down
}

\author{
Eamonn Delahunt*1, Jeremiah O'Driscoll ${ }^{2}$ and Kieran Moran ${ }^{3}$
}

\author{
Address: ${ }^{1}$ School of Physiotherapy and Performance Science, University College Dublin, Republic of Ireland, ${ }^{2}$ Mount Carmel Hospital, Republic \\ of Ireland and ${ }^{3}$ School of Health and Human Performance, Dublin City University, Republic of Ireland \\ Email: Eamonn Delahunt* - eamonn.delahunt@ucd.ie \\ * Corresponding author
}

from Ist Congress of the International Foot \& Ankle Biomechanics (i-FAB) community

Bologna, Italy. 4-6 September 2008

Published: 26 September 2008

Journal of Foot and Ankle Research 2008, I(Suppl I):O7 doi:I0.II86/I757-I I46-I-SI-O7

This abstract is available from: http://www.jfootankleres.com/content/I/SI/O7

(c) 2008 Delahunt et al; licensee BioMed Central Ltd.

\section{Introduction}

Ankle joint taping is a common prophylactic measure used by individuals involved in sports. Little information is available on the effects of ankle joint taping on biomechanical parameters in subjects with FI during functional activities such as jump landing. [1] Thus the aim of this study was to examine the effects of ankle joint taping and exercise on ankle joint frontal and sagittal plane movement in subjects with FI while they performed a jump landing technique.

\section{Methods}

Eleven ( 7 male and 4 female) subjects with a history of unilateral FI volunteered to participate in the study. FI was defined as a score of $\leq 24$ of 30 on the Cumberland Ankle Instability Tool (CAIT). [2] Each subject performed three single leg sagittal plane jump landings under three conditions; condition 1 (no tape), condition 2 (tape), condition 3 (post-exercise tape). The exercise protocol between testing of condition 2 and 3 consisted of a series of hopping, ladder and cutting drills. Joint movement was measured at $250 \mathrm{~Hz}$ using a 12 camera motion analysis capture system (Vicon Oxford Metrics, UK), while initial contact with the ground was identified using the vertical component of ground reaction force. Ankle joint frontal and sagittal plane motion was measured at $50 \mathrm{~ms}$ prior to and at initial contact (IC) with the ground.

\section{Results}

There was no significant effect on ankle joint inversion, either at $50 \mathrm{~ms}$ prior to $\left[\mathrm{F}_{2,18}=1.2, \mathrm{P}=0.32\right]$ or at $\mathrm{IC}$ with the ground $\left[\mathrm{F}_{2,18}=0.4, \mathrm{P}=0.68\right]$. However, there was a significant effect on the angle of ankle joint plantar flexion, both at $50 \mathrm{~ms}$ prior to IC $\left[\mathrm{F}_{2,18}=29.4, \mathrm{P}<0.001\right]$ and at IC $\left[\mathrm{F}_{2,18}=16.1, \mathrm{P}<0.001\right]$. Post hoc analysis revealed that condition 1 (no tape) resulted in significantly greater plantar flexion at $50 \mathrm{~ms}$ prior to IC than condition 2 (tape) $\left[7.7 \pm 3.0^{\circ} ; \mathrm{P}<0.002\right]$ and condition 3 (post-exercise tape) $\left[8.3 \pm 4.8^{\circ} ; \mathrm{P}=0.001\right]$. Similarly, condition 1 (no tape) resulted in significantly greater plantar flexion at IC than both condition 2 (tape) $\left[5.3 \pm 3.2^{\circ} ; \mathrm{P}=0.002\right]$ and condition 3 (post-exercise tape) $\left[5.3 \pm 4.4^{\circ} ; \mathrm{P}=0.01\right]$. No significant differences were evident between condition 2 (tape) and condition 3 (post-exercise tape) [P > 0.05].

\section{Conclusion}

These results indicate that taping acted to reduce the degree of plantar flexion at both $50 \mathrm{~ms}$ prior to and at IC with the ground, and that these reductions were retained even after exercise.

\section{Acknowledgements}

This study was supported by the CPSM bursary of the Irish Society of Chartered Physiotherapists.

\section{References}

I. Cordova ML, et al.: J Athl Train 2002, 37:446-457. 
2. Hiller CE, et al:: Arch Phys Med Rehabil 2006, 87:1235-I24I.

Publish with Bio Med Central and every scientist can read your work free of charge

"BioMed Central will be the most significant development for disseminating the results of biomedical research in our lifetime." Sir Paul Nurse, Cancer Research UK

Your research papers will be:

- available free of charge to the entire biomedical community

- peer reviewed and published immediately upon acceptance

- cited in PubMed and archived on PubMed Central

- yours - you keep the copyright

Submit your manuscript here:

http://www.biomedcentral.com/info/publishing_adv.asp 